\title{
Solar and Wind Energy Sources Interfacing to the Utility Grid Using Five Level Inverter
}

\author{
Dr. G.Chandra Sekhar ${ }^{\# 1,}$ M.Rambabu ${ }^{* 2}$, A.Appa Rao ${ }^{\# 3}$ \\ \#1\& 2 Dept.of EEE, GMR Institute of Technology,Rajam,Andhra Pradesh, India. \\ ${ }^{\# 2}$ Dept.of Power Engineering, GMR Institute of Technology,Rajam,Andhra Pradesh, \\ India. ${ }^{1}$ chandrasekhar.g@gmrit.org \\ 2rambabu.m@gmrit.org \\ 3apparao.a@gmrit.org
}

Abstract: In modern power systems, a little pay raise in the energy effectiveness is a critical change and challenge for power system administrators. This can be accomplished by introducing a perfect and manageable energy source with zero fuel cost.With supposed favorable circumstances, it is most encouraging and quickest developing energy source that speaks to the biggest measure of the renewable energy sources associated with the electric system by and large, a PVCELL and Wind comprises of an alternator with power change gadgets to meet the matrix codes. In such manner, generally, DC to AC power transformation gadgets i.e., inverters go about as interface between the PV CELL and Wind network. The ordinary inverters are two level voltage source converters with restricted capacities for new topologies and control plans. In any case, with the propelled power electronic advances, there is a probability of creating three stage multilevel inverter topologies and complex control procedures. In this way, the innovation will be focused to enhance the ability of customary inverter of PV CELL into a CPD (Converter Pulse to DC Voltage). This sort of exchange diminishes the monetary weight on the PSOs (power system operators) and enhances the power nature of the matrix. In writing, a bit of research has been led on the predefined zone. Photovoltaic energy is a wide sort of efficient power energy. A superior on these systems is expected to benefit as much as possible from energy created by solar based cells. Likewise, there must be a steady adjustment because of the ceaseless variety of power generation. This paper introduces a solitary stage Five-Level course multilevel DC-AC network tied inverter. Every inverter extension is associated with a $200 \mathrm{~W}$ solar oriented board. This paper exhibits a solitary stage Five-Level photovoltaic (PV) inverter and Wind converter topology for network associated PV and Wind systems. This paper displayed areclusive stage Five-Level inverter for Solar and Wind applications. As we obtain energy from wind energy system and which is not constant it may vary with wind speed and frequency of operation throughout the day. In order to interconnect with standard electrical grid, inverter with current control mode is required to eliminate frequency fluctuations. The inverter can operate either in current controlled mode or in voltage controlled mode. Implementation in most cases is based on voltage controlled mode.

Keywords: Converter, Grid,Wind generator, solar energy, High frequency transformer, Five-Level inverter.

\section{INTRODUCTION}

The Demand for renewable energy has expanded essentially throughout the years as a result of deficiency of fossil fuels and nursery impact. The meaning of renewable energy incorporates any sort of energy created from normal assets that is vast or always restored. Case of renewable energy incorporate solar oriented, wind, and hydropower. Renewable energy, because of its free accessibility and its spotless and renewable character, positions as the most encouraging renewable energy assets like solar powered energy, Wind energy that could assume a key part in understanding the overall energy emergency. Among different sorts of renewable energy sources, solarlight based energy and wind energy have turned out to be exceptionally prevalent and requesting because of headway in power hardware procedures [1]. Photovoltaic (PV) sources are utilized today as a part of numerous applications as they have the upsides of successful upkeep and contamination free. Solar powered electric energy request has developed reliably by $20 \%$ to $25 \%$ for every annum in the course of recent years, which is basically because of its diminishing expenses and costs. This decrease has been driven by the accompanying variables. 1) An expanding proficiency of solar oriented cells, 2) Manufacturing innovation upgrades, 3) Economies of scale. PV inverter, which is the heart of a PV system, is utilized to change over DC power acquired from PV modules into ac energy to be encouraged into the matrix. Enhancing the yield waveform of the inverter decreases its individual symphonious substance and, thus, the span of the channel utilized and the level of Electromagnetic Interference (EMI) created by exchanging operation of the inverter [2]. As of late, multilevel inverters have turned out to be more alluring for scientists and makers because of their points of interest over traditional multilevel PWM Inverters. They offer enhanced yield waveforms, littler 
channel size and lower EMI, lower Total Harmonic Distortion (THD). The three basic topologies for multilevel inverters are as per the following: 1) Diode cinched (clamped), 2) Capacitor clamped (flying capacitors), 3) Cascaded H-Bridge inverter. Moreover, a few balance and control procedures have been created or embraced for multilevel inverters, including the accompanying multilevel sinusoidal (PWM), multilevel specific consonant end, and Space Vector regulation. The overview construction of this paper is as shown in Fig. 7. An ordinary single stage Three-Level inverter receives full-connect design by utilizing surmised sinusoidal adjustment system as the power circuits. The yield voltage then has the accompanying three qualities: zero, positive $\left(+V_{d c}\right)$, and negative $\left(-\mathrm{V}_{\mathrm{dc}}\right)$ supply DC voltage (accepting that $\mathrm{V}_{\mathrm{dc}}$ is the supply voltage). The consonant segments of the yield voltage are controlled by the bearer recurrence and exchanging capacities. Along these lines, their Harmonic lessening is restricted to a specific degree. To conquer this constraint, this paper exhibits a Five-Level PWM inverter whose yield voltage can be spoken to in the accompanying Five Levels: $0,+\frac{1}{2} V_{d c}, V_{\mathrm{dc}},-\frac{1}{2} \mathrm{~V}_{\mathrm{dc}}$, and $-V_{\mathrm{dc}}$. As the quantity of yield levels builds, the consonant substance can be lessened. This inverter topology utilizes two reference signals, rather than one reference sign, to produce PWM signals for the switches. Both the reference signals $V_{\text {ref1 }}$ and $V_{\text {ref2 }}$ are indistinguishable to each other, aside from counterbalance esteem identical to the plentifulness of the transporter signal $\mathrm{V}_{\text {carrier }}[3]$.

\section{MULTILEVEL INVERTER AND PV INTERFACE}

A review of the system is appeared in Fig. 1. The center part of this inverter configuration is the four-switch mix appeared in Fig. 1. By associating the DC Source to the AC yield by various mixes of the four switches, Q11, Q12, Q13, and Q14, three diverse voltage yield levels can be created for every DC source, $+V_{\mathrm{dc}}, 0$, and $-\mathrm{V}_{\mathrm{dc}}$. A course inverter with $\mathrm{N}$ information sources will give $(2 \mathrm{~N}+1)$ levels to blend the AC yield waveform. The DC source in the inverter originates from the PV clusters, and the changing signs originate from the multicarrier sinusoidal pulse width modulation (SPWM) controller. The Five-level inverter associates Five diode clampedspans in arrangement and is controlled by five arrangements of various SPWM signs to produce a close sinusoidal waveform [4] [9-11]. The association with the system is done through a variable transformer to guarantee that whenever the quantity of utilized can be controlled, the network voltage created by the inverter is met furthermore to give more adaptability to the investigation since irradiance levels won't be sufficient. Hence, an extra settled $10 \mathrm{mH}$ inductance was included as the association inductance for power exchanging mode. The individual solar oriented board yield power is relative to solar based irradiance varieties that happen amid the day. The MPPT calculation will work detecting the yield control so no input from the individual boards is given to diminish the quantity of sensors [5] [12]. As can be found in Fig. 1, the lower boards, as far as control signs, will convey more energy than the upper boards. Keeping in mind the end goal to uneven energy to be drawn from the boards by the inverter, an alternate inverter control approach for the SPWM plan is proposed here to be utilized with the solar powered boards that can represent the voltage profile variety of the boards that happens amid the day. The MPPT and system synchronization calculation are nourished by yield and voltage ebb and flow signs to create the door driver signals as appeared in Fig. 2. In Fig. 3 are demonstrated the inverter and its cycle by cycle SPWM control technique [13]. It is fancied to get the same measure of power from every string, which can't be accomplished utilizing a customary SPWM approach. For instance, the lower boards [6].

\section{STANDARD OF SOLAR ENERGY}

Solar powered energy is accessible in wealth in most parts of the world. The measure of solar oriented energy occurrence on the world's surface is approximately1.5 x 1018kWh/year [1], which is around 10,000 times the present yearly energy utilization of the whole world. The thickness of power emanated from the solar (alluded to as solar oriented energy consistent) is $1.373 \mathrm{~kW} / \mathrm{m}^{2}$. Solar oriented cell is a gadget which changes over photons in Solar beams to direct-current (DC) and voltage. The related innovation is called Solar Photovoltaic (SPV). A common silicon PV cell is a meager wafer comprising of a slight layer of phosphorous-doped (N-sort) silicon on top of a thicker layer of boron-doped (P-sort) silicon. An electrical field is made close to the top surface of the cell where these two materials are in contact (the P-N intersection). At the point when the daylight hits the semiconductor surface, an electron springs up and is pulled in towards the N-sort semiconductor material. This will bring about more negatives in the n-sort and more encouraging points in the P-sort semiconductors, creating a higher stream of power [7]. 


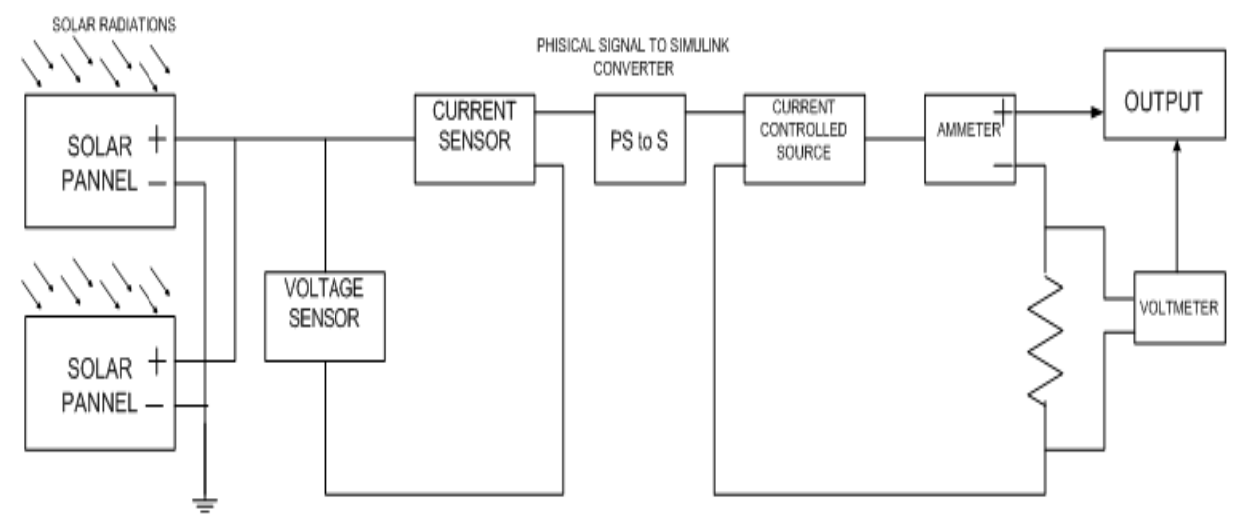

Fig. 1. Solar diagram

\section{MODELLING OF SOLAR CELL}

A solar cell is the building block of a solar panel. A photovoltaic module is formed by connecting many solar cells in series and parallel. Considering only a single solar cell; it can be modelled by utilizing a current source, a diode and two resistors. This model is known as a single diode model of solar cell shown in the Fig. 2. Two diode models are also available but only single diode model is considered here. The modeling diagram of solar energy system is as shown in fig. 3.

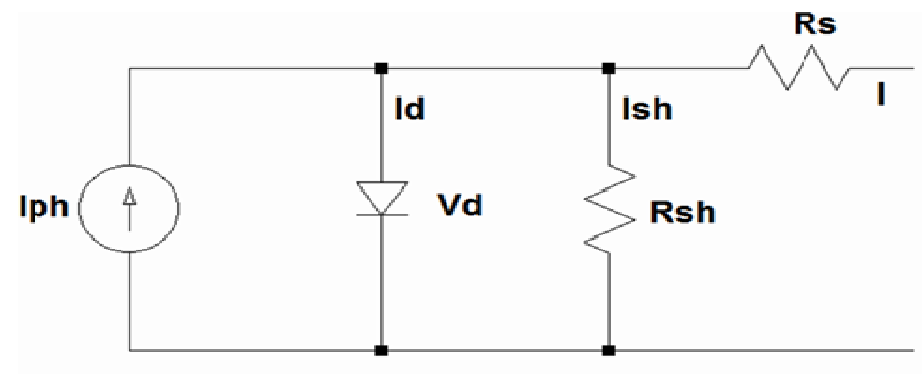

Fig.2. Circuit model of PV solar cell

\section{EFFECT OF VARIATION OF SOLAR IRRADIATION}

The P-V and I-V curves of a solar cell are highly dependent on the solar irradiation values. The solar irradiation as a result of the environmental changes keeps on fluctuating, but control mechanisms are available that can track this change and can alter the working of the solar cell to meet the required load demands. Higher is the solar irradiation, higher would be the solar input to the solar cell and hence power magnitude would increase for the same voltage value shown in the Fig. 3. With increase in the solar irradiation the open circuit voltage increases. This is due to the fact that, when more sunlight incidents on to the solar cell, the electrons are supplied with higher excitation energy, thereby increasing the electron mobility and thus more power is generated.

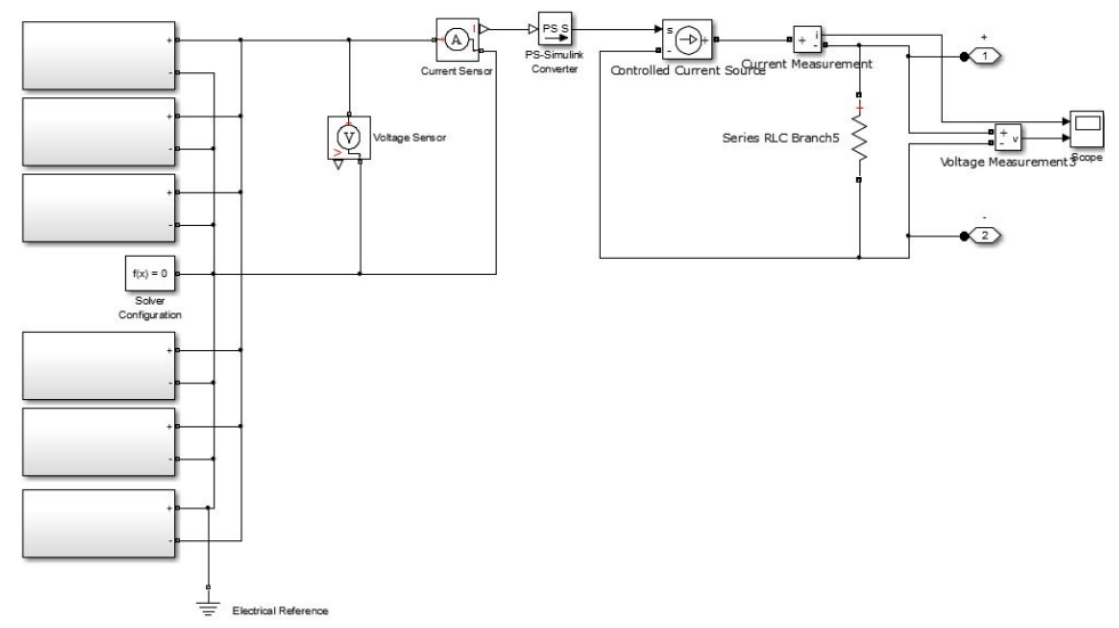

Fig. 3MATLAB modeling diagram of Solar Energy system 


\section{WIND ENERGY CONVERSION SYSTEM}

Variable speed wind turbine system is extensively used by most of the WECSnow a days due to its remarkable achievement. Doubly fed induction generator (DFIG) and permanent magnet synchronous generator (PMSG) connected variable speed wind turbine are popular now these days. In DFIG the stator is connected to the grid and rotor circuit controlled by the power electronic converter and can maintain operational speed around $\pm 30 \%$ of synchronous speed, hence it has a control on reactive power to maintain voltage stability during some disturbances. DFIG have controlled over rotor voltage and current which help it to maintain synchronized with the grid at variable wind speed. The converter handle $25-30 \%$ of mechanical power to the grid and rest is connected directly to the grid by stator [8]. But in case of PMSG, it is connected to thegrid through power electronic converter fully, and even

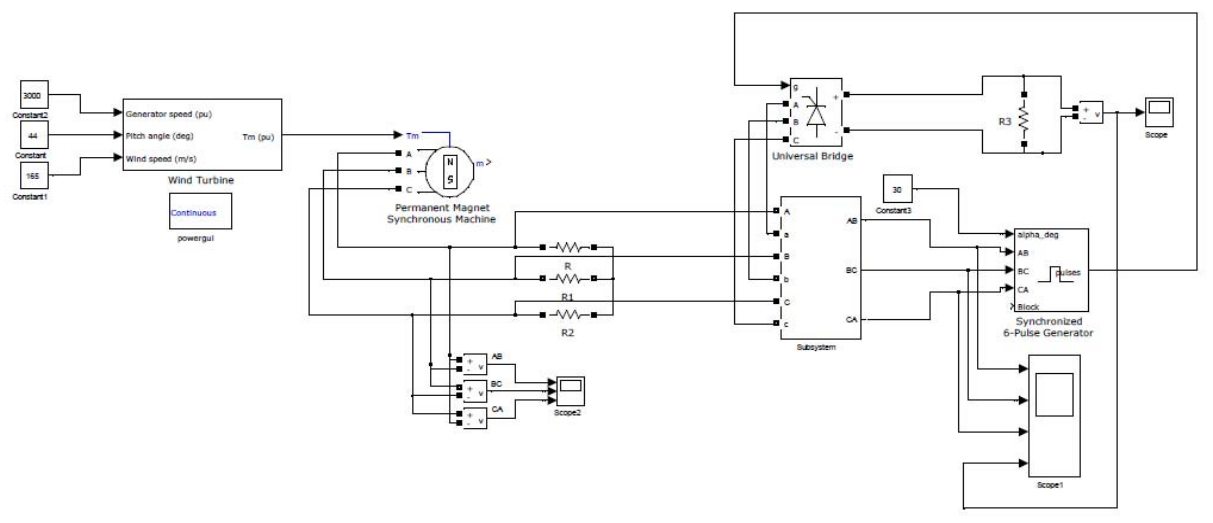

Fig. 4.Wind energy conversion based on PMSG

PMSG can omit the difficult gearbox system. Speed of PMSG is controlled by pulse width modulation converter. The output power of the PMSG is supplied to the grid through the help of generator side converter and grid side converter. As shown in Fig.4 MATLAB simulation of wind energy system is designed. Harmonic reduction method can be applied to any of the system to improve power quality. In thispaper PMSG based wind turbine has been taken and multilevel inverter has been applied on it to reduce THD.

\section{FIVE-LEVEL INVERTER TOPOLOGY}

The proposed single phase five level inverter topology is shown in Fig. 5. The inverter adopts full bridge configuration with an auxiliary circuit. PV arrays are connected to the inverter through a dc -dc boost converter. The $\mathrm{dc}$ - dc boost converter is used to step up inverter output voltage $\mathrm{V}_{\text {in }}$ to be more than 2of grid voltage to ensure power flow from the PV arrays and wind system into the grid. A filtering inductance $\mathrm{L}_{\mathrm{f}}$ is used to filter the current injected into the grid. The injected current must be sinusoidal with low harmonic distortion. The switching instant is determined from the crossing of the carrier and the modulating signal.

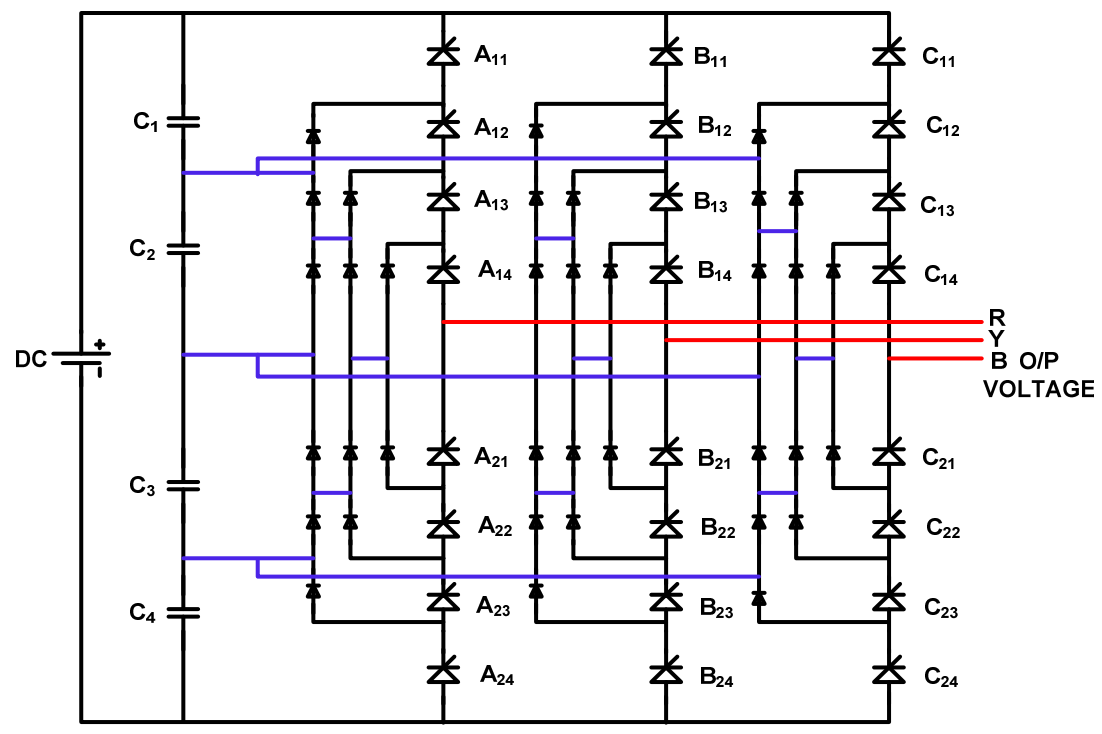

Fig. 5Five Level inverter (diode clamped) 


\section{OPERATING PRINCIPLE OF THE FIVE LEVEL DIODE CLAMPED INVERTER}

Because PV arrays and wind are used as input voltage sources, the voltage produced by the array in known as $V_{\text {arrays }} . V_{\text {arrays }}$ boosted by a dc-dc boost converter to exceed $2 V_{g}$. The proposed inverter is to generate Five Level output voltages, i.e. zero, $+\frac{1}{2} \mathrm{~V}_{\mathrm{dc}},+\mathrm{V}_{\mathrm{dc}},-\frac{1}{2} \mathrm{~V}_{\mathrm{dc}}$ and $-\mathrm{V}_{\mathrm{dc}}$. Auxiliary circuit which consists of four diodes and a switch s1 is used between the dc bus capacitor and the full bridge inverter [5]. Proper switching control of auxiliary circuit can generate half level of PV and Wind supply voltage, i.e. $+\frac{1}{2} \mathrm{~V}_{\mathrm{dc}}$ and $-\frac{1}{2} \mathrm{~V}_{\mathrm{dc}}[4]$. The model output of Five Level inverter is as shown in Fig. 6.

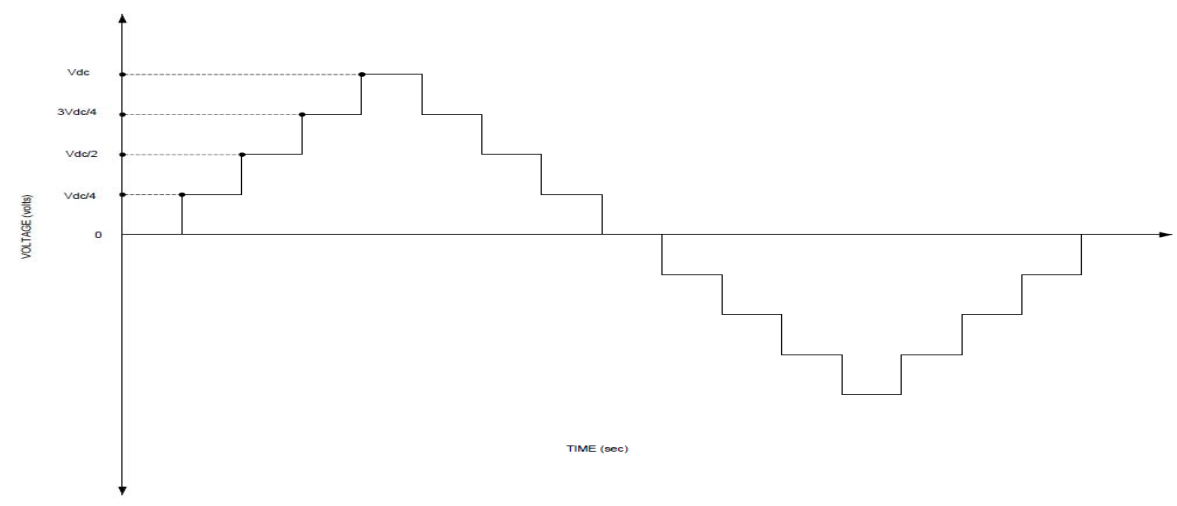

Fig. 6. Ideal Five Level Inverter Output Voltage

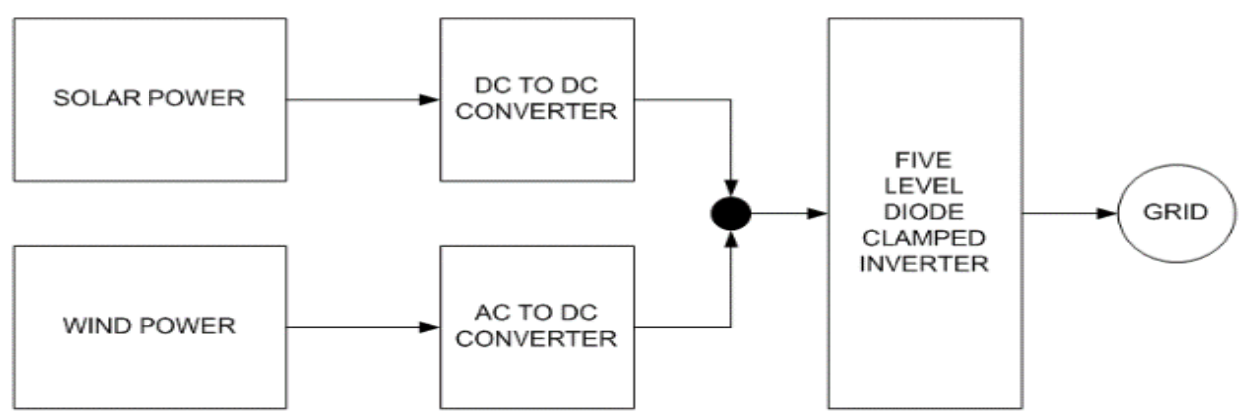

Fig. 7 Overview of the Proposed System

VIII. DIODE CLAMPED FIVE LEVEL INVERTER

The most commonly used multilevel topology is the diode clamped inverter, in which the diode is used as the clamping device to clamp the dc bus voltage so as to achieve steps in the output voltage. Thus, the main concept of this inverter is to use diodes to limit the power devices voltage stress. The voltage over each capacitor and each switch is $V_{d c}$. An $n$ level inverter needs (n-1) voltage sources, 2(n-1) switching devices and (n-1) (n-2) diodes. By increasing the number of voltage levels the quality of the output voltage is improved and the voltage waveform becomes closer to sinusoidal waveform [6] [7].

\begin{tabular}{|l|l|l|l|l|l|l|l|l|}
\hline $\begin{array}{l}\text { Switches } \\
\text { Voltage }\end{array}$ & $\mathbf{A}_{\mathbf{1 1}}$ & $\mathbf{A}_{\mathbf{1 2}}$ & $\mathbf{A}_{\mathbf{1 3}}$ & $\mathbf{A}_{\mathbf{1 4}}$ & $\mathbf{A}_{\mathbf{2 1}}$ & $\mathbf{A}_{\mathbf{2 2}}$ & $\mathbf{A}_{\mathbf{2 3}}$ & $\mathbf{A}_{\mathbf{2 4}}$ \\
\hline $\mathrm{V}_{5}=\mathrm{V}_{\mathrm{dc}}$ & 1 & 1 & 1 & 1 & 0 & 0 & 0 & 0 \\
\hline $\mathrm{V}_{4}=3 \mathrm{~V}_{\mathrm{dc}} / 4$ & 0 & 1 & 1 & 1 & 1 & 0 & 0 & 0 \\
\hline $\mathrm{V}_{3}=\mathrm{V}_{\mathrm{dc}} / 2$ & 0 & 0 & 1 & 1 & 1 & 1 & 0 & 0 \\
\hline $\mathrm{V}_{3}=\mathrm{V}_{\mathrm{dc}} / 4$ & 0 & 0 & 0 & 1 & 1 & 1 & 1 & 0 \\
\hline $\mathrm{V}_{1}=0$ & 0 & 0 & 0 & 0 & 1 & 1 & 1 & 1 \\
\hline
\end{tabular}

Fig. 8. Switching states of Five Level inverter(Diode clamped) 


\section{SIMULATION RESULTS}

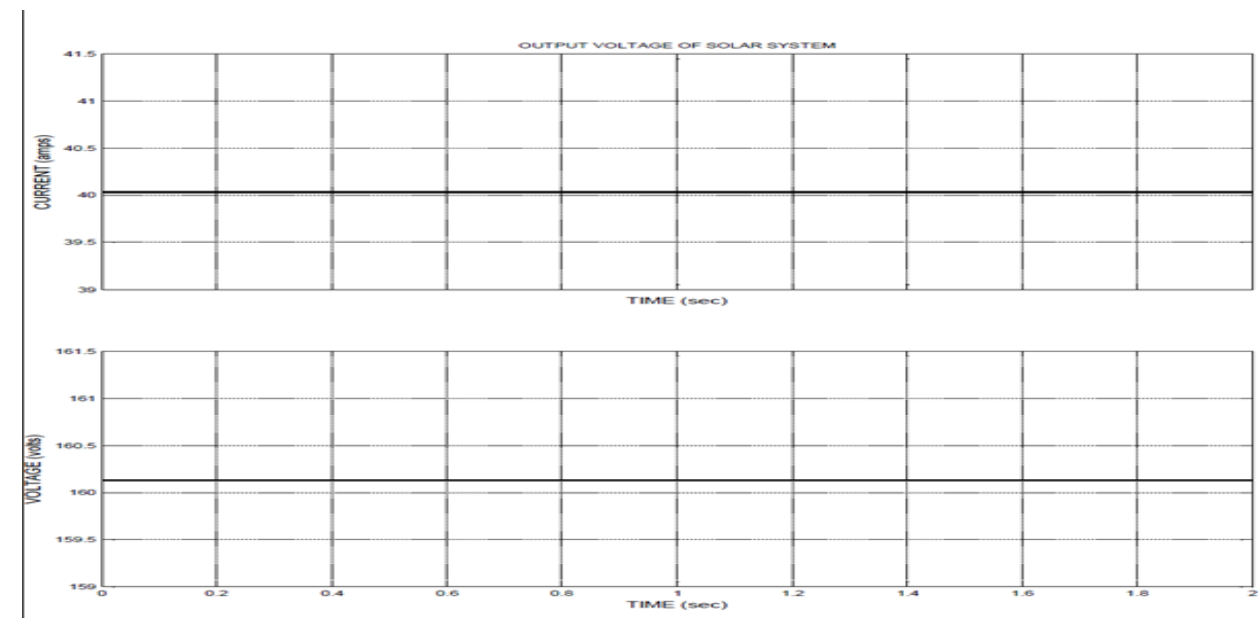

Fig.9 Solar Energy System Output
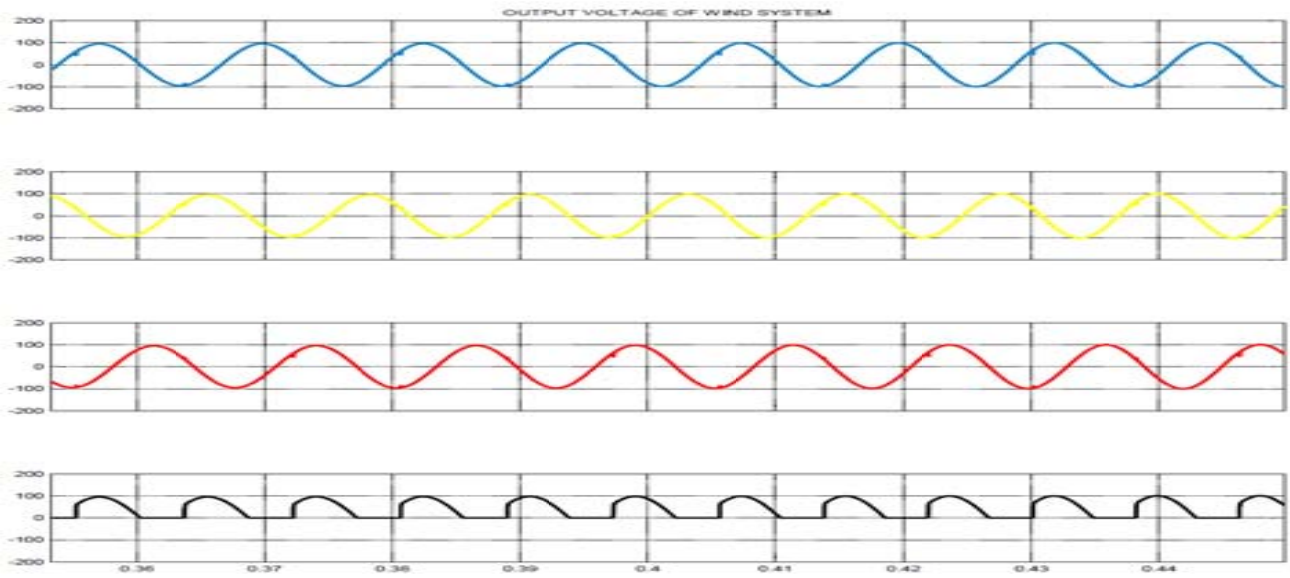

Fig.10 Wind Energy System Output
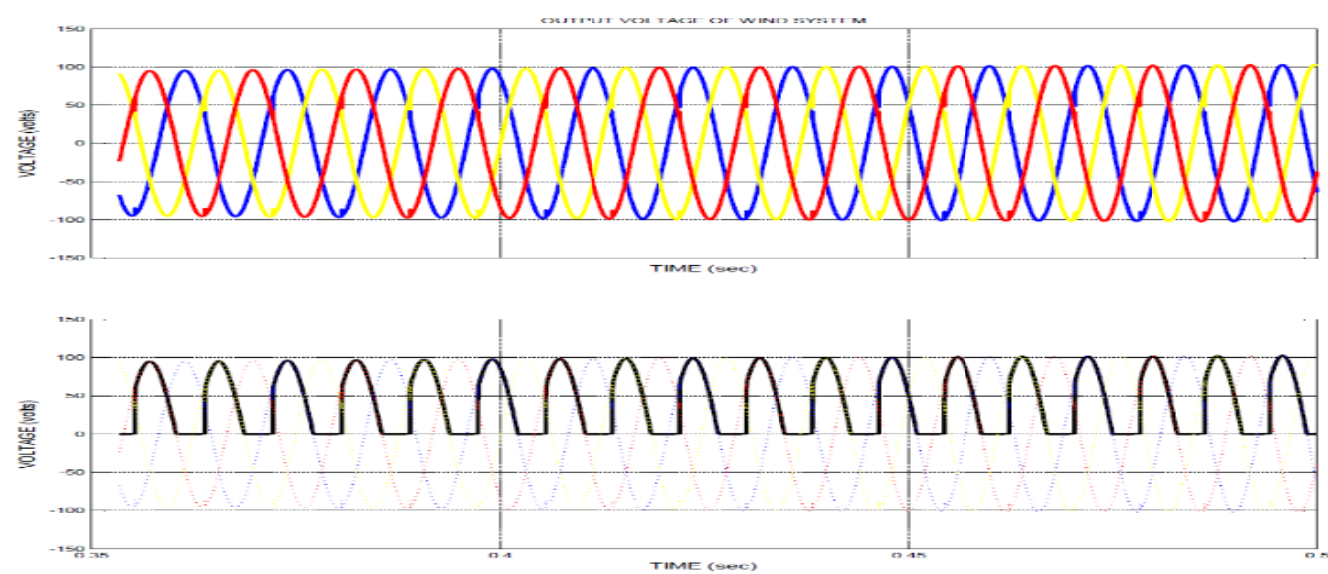

Fig.11 three phase output of Wind Energy System 

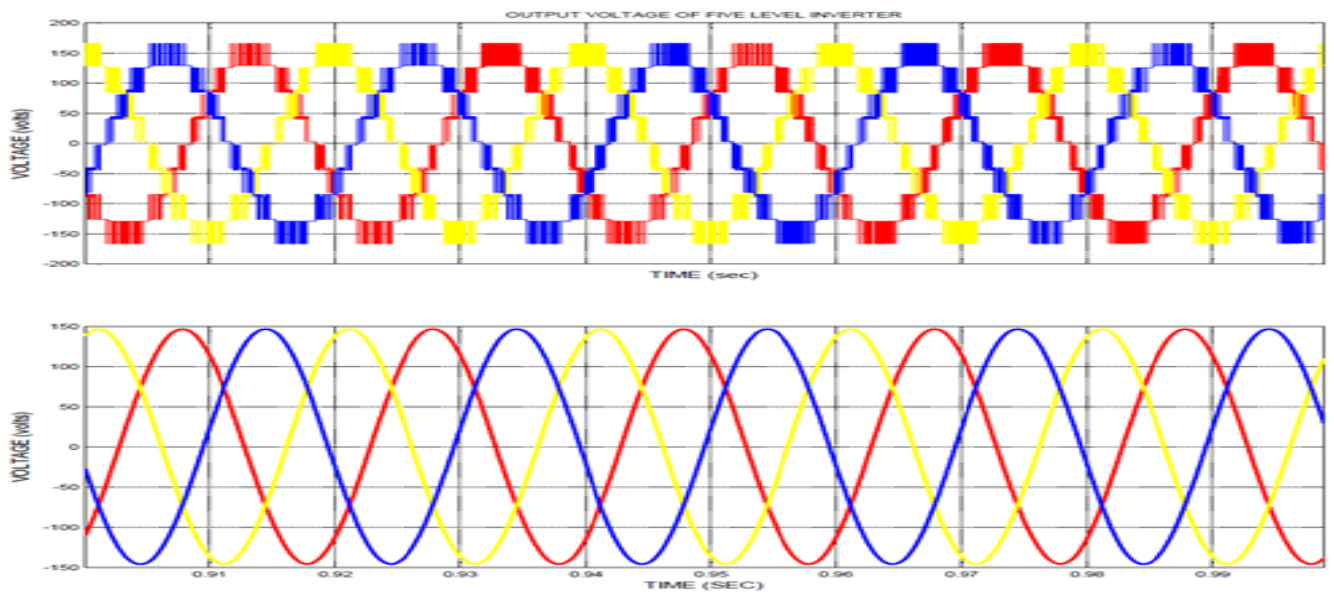

Fig.12 Output of Solar and Wind Energy Sources Interfacing with Utility Grid using Five-Level inverter

\section{CONCLUSION}

It has been comprehended from the simulationresultsthat the overall efficiency of the developed Five-Level inverter is 95\% which is more than the traditional DC to AC inverter. The two-level inverter has the least cost and weight in correlation with alternate topologies. Be that as it may, it has high THD and it is not commonsense to have a yield voltage with high such THD. The outline of the Five-Level multilevel inverters is by all accounts superior to the Nine-Level multilevel inverters. By expanding the quantity of levels, the expense and weight of the multilevel inverter will be expanded. So this topology is appropriate for industrial drives.

\section{REFERENCES}

[1] NasrudinAbd. Rahim, Mohamad Fathi Mohamad Elias, Wooi Ping Hew, IEEE transaction. Industry Electronics, "Design of filter to reduce harmonic distortion in industrial power system”, Vol. 60, No: 8, 2943- 2956, August 2011.

[2] Cecati.C, F. Ciancetta, and P. Siano, "A multilevel inverter for photovoltaic systems with fuzzy logic control," IEEE Trans. Ind. Electron., vol. 57, no. 12, pp. 4115-4125, Dec. 2010.

[3] R. Seyezhai, B.L.Mathur, "Hybrid Multilevel Inverter using ISPWM Technique for Fuel Cell Applications”, International journal of computer and applications, vol. 9, no. 1, 2010.

[4] S.Khomfoi, A. Chatrchai,”A 5-Level Cascaded Hybrid Multilevel Inverter for interfacing with Renewable Energy Resources”, Proceedings of the 2009 Electrical Engineering/Electronics, Computer, Telecommunications, and Information Technology International Conference, (ECTI-CON 2009), 6-9 May 2009, Pattaya, Thailand..

[5] F.S.Kang, "A modified cascade-transformer-based multilevel inverter and its efficient switching function,” Electric Power Systems Research ,vol. 79, pp. 1648-1654, 2009.

[6] S. Khomfoi, L. M. Tolbert, "Multilevel Power Converters," PowerElectronics Handbook, 2nd Edition Elsevier, 2007, ISBN 978-0- 12088479-7, Chapter 17, pp. 451-482.

[7] P. C. Loh, D. G. Holmes, and T. A. Lipo, "Implementation and control of distributed PWM cascaded multilevel inverters with minimum harmonic distortion and common-mode voltages,” IEEE Trans. Power Electron., vol. 20, no. 1, pp. 90-99, Jan. 2005.

[8] M. D. Manjrekar, P. Steimer and T. A. Lipo, "Hybrid Multilevel Power Conversion System: A Competitive Solution for High Power Applications,” IEEE Trans. On Industry Applications, Vol. 36, No. 3, pp. 834-841, May/June 2000.

[9] S. Khomfoi, L. M. Tolbert, "Multilevel Power Converters," "2nd ed.Power Electronics Handbook,” Elsevier, 2007, ch. 31, pp. 1-50.

[10] NattapatPraisuwanna, SurinKhomfoi, Leon M.Tolbert, “A Hybrid Cascaded Multi level Inverter Application For Renewable Ener- gy Resources Including a ReconFiguration Technique” proceedings of the 2010 International Power Electronics Conference, Bangkok, 10520, Thailand.

[11] JIANG You-hau, CAO Yi-long, GONG You-min, “A Novel Topology of Hybrid Multilevel Inverter with Minimum Number of Separate DC sources", journal of shanghai university(English Edi- tion) 2004.

[12] R.Seyezhai and B.L.Mathur, “Harmonic evaluation of multicarri- er PWM techniques for cascaded multilevel inverter”, in Proc. 2nd International Conference on Electrical Engineering and its Applications, Algeria, ICEEA 2008, 20- 21 May 2008, pp. 3 - 8.

[13] Zhou Jinghua, Li Zhengxi,” Research on Hybrid Modulation Strategies Based on General Hybrid Topology of Multilevel Inverter” International Symposium on Power Electronics, Electrical Drives, Automation..2008.

\section{AUTHOR PROFILE}

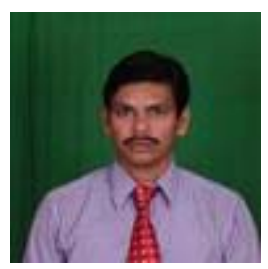

Dr.G. Chandra Sekhar received his B.E(EEE) in the year 1998 from Andhra University and M Tech in High Voltage Engineering in the year 2001 from JNTU College of Engineering, Kakinada, E.G(Dt), AP, India, and Ph.D from JNTU, Kukatpally, Hyderabad. He has published 12 International Journal publications and two international conference proceedings. His area of interest includes Electrical Power systems, Electrical Machines, Electrical Circuits, renewable energy connected to grid, and Multiphase transmission and Member of IEEE. systems. He is life member of Indian Society for TechnicalEducation(ISTE), Fellow of IEI 


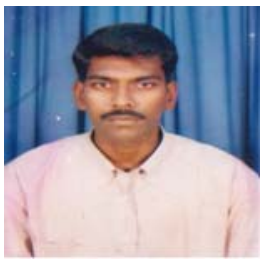

M.Rambabu received the B.Tech in electrical and electronic engineering (EEE) from GMRIT Rajam India in 2002, the M.Tech degree from JNTU Hyderabad ,India in 2009. He is currently working as an Assistant Professor at the GMRIT Rajam, India. He is pursuing Ph.D in JNTU, Kakinada, India. His areas of interest are Power Systems protection, Renewable Energy Sources

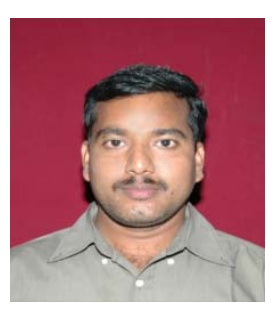

Mr. A.Apparao received his B.E(EEE) in the year 1998 from Andhra University and M Tech(Information Technology in Power Engineering) in the year 2002 from JNTU College of Engineering, Hyderabad, AP, India. He is Pursuing Ph.D. from GITAM University, Visakhapatnam, AP, India. He has published seven International Journal publications and two international conference proceedings. His area of interest includes Electrical Power systems, Distribution Generation and renewable energy systems connected to grid. He is life member of Indian Society forTechnical Education(ISTE) and Associate Member of IE(India). 